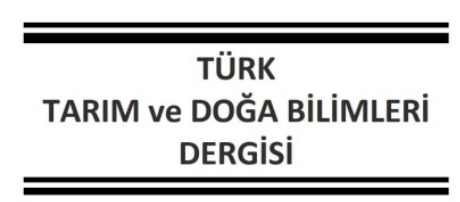

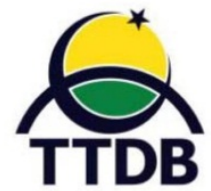

www.dergipark.gov.tr/turkjans

Araştırma Makalesi
$\begin{gathered}\text { The Effects of Harvested Rainwater on the Performance and Some Slaughter Parameters of } \\ \text { Broilers }{ }^{\&}\end{gathered}$

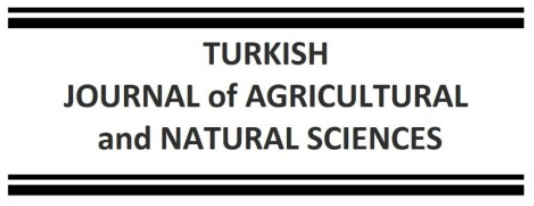
Broilers \&

\author{
Sabri Arda ERATALAR*, Bahadır Cem KAVECi
}

\begin{abstract}
Bolu Abant İzzet Baysal Üniversitesi, Ziraat Fakültesi, Kanatı Hayvan Yetiştiriciliği Bölümü, Bolu, Türkiye
*Corresponding author: ardaeratalar@ibu.edu.tr
\end{abstract}

Received: 19.02.2021 Revised in received: 23.03.2021 Accepted: 08.04.2021

\begin{abstract}
This study was organized to examine the effects of the use of rainwater lost from roofs as the water source for broilers on the performance and some of the basic carcass and meat quality parameters. In the research, day old 96 Ross 308 broiler chicks were used. In the experiment, the birds were separated to two treatment groups and the birds given harvested rainwater were distributed to 4 pens and the birds given deepwell water were kept in other 4 pens in the research house. Performance criteria were analyzed from birds with mixed sex, where the carcass and meat $\mathrm{pH}$ were analyzed from the data obtained from male broilers. According to the findings obtained from the research, there was no statistically significant difference between the groups in terms of feed consumption, water consumption, live weight, live weight gain and feed conversion ratio. Also, there was no significant differences between the groups in terms of edible internal organs and meat $\mathrm{pH}$ as well $(\mathrm{P}>0.05)$. According to the results of the experiment, it can be stated that harvested rainwater can be used as a substitute for deep-well water and causes no change in terms of performance and carcass characteristics. It is thought that organizing detailed studies including economics and animal health will be positive in terms of academic knowledge and industry soon.
\end{abstract}

Key words: Harvested rainwater, broiler, performance, meat quality, edible giblets

\title{
Hasat Edilmiş Yağmur Suyunun Etlik Piliçlerde Performansa ve Bazı Kesim Parametrelerine Etkileri \\ $\overline{O ̈ z}$
}

Çatılardan kaybolan suların etlik piliç yetiştiriciliğinde kullanılma olanaklarının performansa ve temel karkas ve et kalite parametrelerinden bazılarına etkilerini incelemek amacıyla bu çalışma düzenlenmiştir. Araştırmada, 96 adet günlük yaşta Ross 308 etlik piliç civcivi kullanılmıştır. Hasat edilmiş yağmur suyu verilen 4 ve kuyu suyu verilen 4 bölme olarak düzenlenmiş olan denemede karışık cinsiyetten etlik piliçlere bakılmış, performans kriterleri bu veriler üzerinden; karkas ve et kalite parametreleri de erkek piliçler üzerinden incelenmiştir. Araştırmadan elde edilen bulgulara göre, performans kriterlerinden yem tüketimi, su tüketimi, canlı ağırık, canlı ağırlık artışı ve yem dönüşüm oranı verileri bakımından gruplar arasında istatistik açıdan önemli bir farklılığa rastlanmamıştır. Bununla birlikte karkas özellikleri, yenilebilir iç organlar ve et $\mathrm{pH}$ 'sı bakımından da gruplar arasında önemli bir farklılık tespit edilmemiştir ( $P>0.05)$. Deneme sonuçlarına göre, yağmur suyunun kuyu suyuna ikame olarak kullanılabileceği, performans ve karkas özellikleri bakımından herhangi bir farklılığa neden olmadı̆̆ı ifade edilebilir. Bununla birlikte, ekonomiklik, hayvan sağlık durumunu da içine alan ayrıntılı çalışmaların düzenlenmesi akademik bilgi ve sektör açısından olumlu olacaktır.

Anahtar kelimeler: Hasat edilmiş yağmur suyu, etlik piliç, performans, et kalitesi, yenilebilir iç organlar 


\section{Introduction}

Chicken meat production and consumption has increased rapidly both in the world and in our country in recent years compared to previous years. Annual chicken meat consumption in Turkey vary according to zone, yearly income status, marital status, living in a rural or urban and consumers' lifestyle, is reported to be $22 \mathrm{~kg}$ per capita (Anonymous, 2020b).

It is important to provide fresh, clean water freely to the birds in production in order to achieve the desired performance in broiler breeding. (Leeson and Summers, 2008).

In our daily life, drinking and utility water is obtained from underground sources, natural and artificial lakes, rivers, wells and, although it is expensive in terms of making it usable, by treating sea water in some compulsory cases. However, the most important of these water resources we have mentioned is precipitation falling on the earth (Bayramoğlu et al., 2013).

Water is the most critical nutrient in chicken breeding to meet the needs of animals and to gain mass by utilizing the optimum amount of feed. As it is known, water is the largest component of the body and constitutes approximately $70 \%$ of the total body weight. The water content in the body is directly related to the protein content. As the animal ages, the amount of fat in the total weight gained increases and the percentage of water in the total body weight decreases. Poultry obtain this amount by drinking water, feed, and catabolism of body tissues as a natural part of growth and development. (Leeson \& Summers, 2008; Eleroğlu and Sarıca, 2004).

Actually, there are two solutions to ensure the sustainability of fresh water consumption in terms of physical alternatives, as the existing fresh water resources are rapidly polluting and depleting. First is to find alternative or additional water resources that are currently being used. Second is to use the limited amount of water resources more effectively and efficiently. The collection and reuse of rainwater from rainfall surfaces is one of these methods. This method used is called rainwater harvesting. Rainwater harvesting is an important development among the methods performed at lower costs recently (Tarı, 2009; Örs et al., 2011; Silkin, 2014).

Harvested rainwater is used in some skyscrapers for grey water (usage water in sinks and lavatories) in high populated cities, some animal farms breeding cattle and swine for cleaning water which is needed in great mass in some countries. Therefore great savings are made in terms of water and budget. Different countries are trying to implement different methods, laws and supports in order to ensure and spread the use of rainwater harvesting (Karahan, 2011; Şahin and Manioğlu, 2011).

Rainwater falling on the roof surface is transferred to the water tank located on the ground surface or to water tanks located or built underground through the grooves on the structure and stored. Storage structures are usually made of plastic, fiberglass, concrete or stainless steel (Kantaroğlu, 2009). Rainwater can be used to serve different purposes by harvesting from building roofs or harvesting from other surfaces. It can be used as domestic water (cleaning, shower, bath, sink, etc.) in houses, as irrigation water in plant breeding, in watering in animal breeding, in areas such as disinfection of facilities (Alparslan et al., 2008).

The surface where rainwater is collected is called the collection surface. Building roofs, balconies and courtyards have the most suitable surfaces to collect rainwater, so rainwater can be collected from these areas. The systems direct the rainwater collected from the roofs, balconies and similar surfaces of the buildings to the rain water collection tank. The most preferred building materials for rain gutters are galvanized steel, vinyl, aluminum and PVC, which is frequently used today. Leaf and sand holder filters prevent leaves or larger materials brought by rainwater from the collection surfaces from entering the gutters. All of the rainwater coming to the filters from the collection areas cannot be transferred to the tanks, but more than $90 \%$ can be transferred. This transfer rate varies according to the filter quality and efficiency. Leaf catchers used in transfer hold the leaves and leaf fragments brought by the rainwater, while other filters in the gutters lubricate the smaller pieces and thus enable cleaner rainwater to be transmitted to the storage tanks (İncebel, 2012).

The rainwater is collected from the rainwater tank with sieves and separator materials by flowing from the collection areas. It is important to keep the harvested water at an appropriate temperature to reduce bacterial growth. For this reason, storage tanks are usually installed under the ground close to the buildings (Incebel, 2012).

Rainwater harvesting system, as data of the rainfall capacity of Turkey as seen in Figure 1 illustrates that it is particularly suitable for poultry production in relation to rainfall patterns. The precipitation rate per square meter is particularly high in mountainous coastal areas $(1,000-2,500$ $\mathrm{mm}$ /year), and as we continue towards inland, the precipitation rate per square meter decreases as 
seen in Figure 1. The need for water used as irrigation water has recently increased to a considerable amount and has become an important issue in terms of the reduction and disappearance of non-renewable scarce resources both in economically and environmentally. For this reason, efforts to bring the wastewater, which are currently tried to be reused in some communal living areas, to be used by people by recycling are currently very insufficient. When these situations are taken into consideration, it is obvious that the water obtained with rainwater harvesting in regions where the rainfall regime is suitable together with other water obtaining methods used will provide high benefits both economically and environmentally (Tanık, 2017).

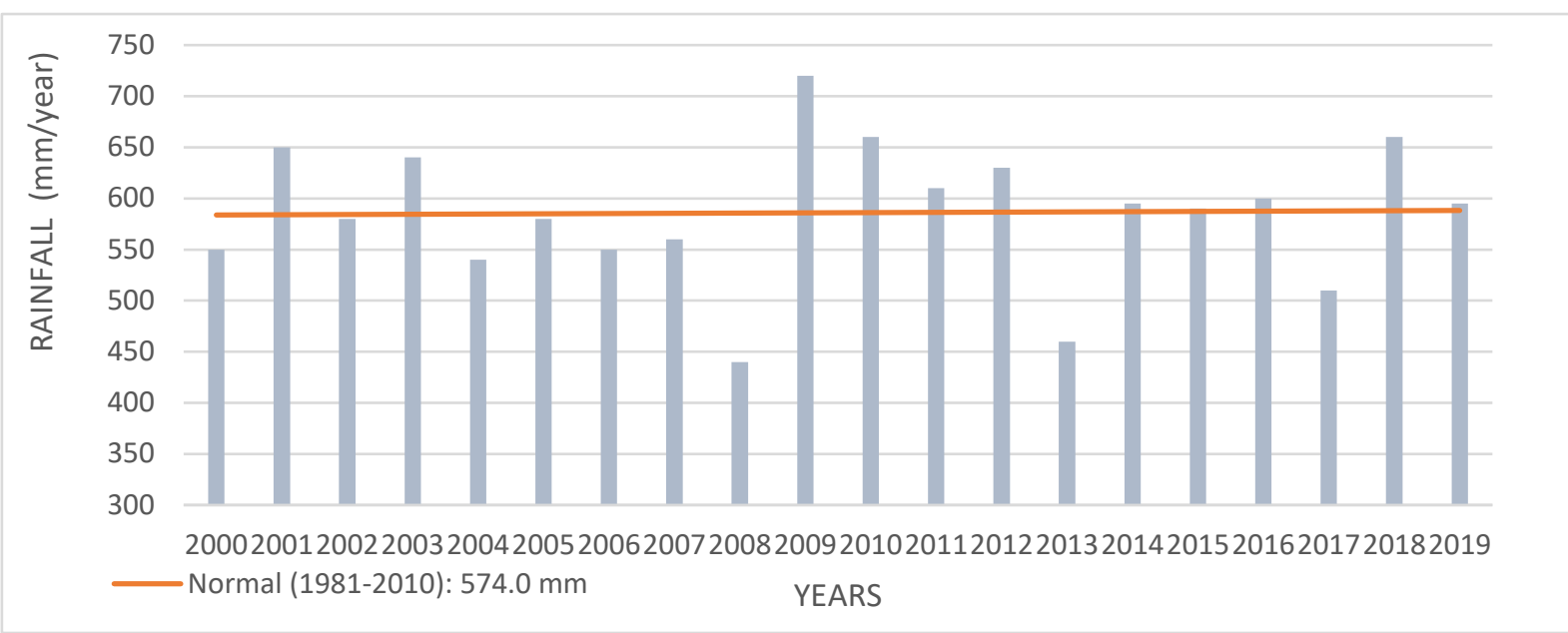

Figure 1. Rainfall in Turkey for the years 2000-2019 (Anonymous, 2020a)

\section{Material and Methods Water Material}

In the research, two groups were used as drinking water, deep well water $(75 \mathrm{~m})$ and harvested rainwater (from rooftop). The water resources were previously analyzed by provincial directorate of agriculture laboratories with standard methods and found to be within acceptable limits in terms of nitrate, nitrite and other heavy metals and not containing any bacteria and coliforms, conclusively found to be drinkable.

\section{Live Material}

The live material of the experiment was composed of Ross-308 broiler chickens of mixed sex obtained from a private sector company founded in Bolu province. The trial layout was divided into two groups using harvested rainwater $(\mathrm{R})$ and well water as the control group (C), and each group had a total of four trial pens and a total of 96 chicks with 12 chicks in each pen with actual rearing conditions. In order to compensate deaths for acquiring the actual stocking density, 12 chicks were kept ready to be used in the experiment in a separate compartment under the same conditions for $\mathrm{R}$ and $\mathrm{C}$.

\section{Feed Material}

Broiler chick feed between days 0-10, grower feed between days 11-21, finisher feed between days 22-35 days and pre-slaughter diet was used in the last week before slaughter (days 36-42). The chemical composition of the feeds used during the trial is given in Table 1.

\section{Rearing Conditions}

The experiment was carried out in the trial unit of Bolu Abant İzet Baysal University, Faculty of Agriculture, Department of Poultry Science. The research and development house is $60 \mathrm{~m}^{2}$ in size, and it is a prefabricated building insulated with sandwich panel. It has automated ventilation, heating, cooling and lighting system. For heating electric radiators (Flavel $\mathrm{R}$ 3000, Turkey) were used, for ventilation two $1100 \mathrm{~m}^{3} /$ hour capacity minimum ventilation fans (Gardener BPP 30 Turkey) and for cooling $4000 \mathrm{~m}^{3} /$ hour capacity (Gardener BSM 400, Turkey) fan was used. For illumination, 9-watt LED bulbs with 6500 lumens lighting capacity were used right above each pen. The building has been designed in a way that fully meets the industrial conditions. 3 broiler (broiler) nipple drinkers attached to a $50 \mathrm{~cm}$ nipple pipe as a drinker were organized separately for each compartment. Separate water tanks with a capacity of 20 liters were placed in each compartment and the water was refreshed daily and as needed. Each time the water was added, the consumption amount was recorded. $10 \mathrm{~kg}$ capacity bucket type hanging feeders were placed 
separately in each compartment. During the process of adding the feed daily, the consumption amount was calculated. A digital precision balance with $\pm 1 \mathrm{mg}$ precision was used for weighing feeds and animals (Radwag AS220R2, Poland).

The pens in the house were $2 * 2 \mathrm{~m}$ in width and $1.25 \mathrm{~m}$ high, with doors $0.75 \mathrm{~m}-1.25 \mathrm{~m}$ in size and were surrounded by steel wire mesh (chicken wire). The chicks were placed in these pens randomly in order to ensure that the animals from the experimental and control groups had equal conditions. Also it was ensured that the animals from both groups were evenly distributed in the house considering fan side, entrance door side and north and south sides of the house. Sawdust of suitable size was used as litter material. The house and the equipment were disinfected properly before the trial period to avoid any health problems.

Table 1. Chemical composition of the feed materials used in the trial.

\begin{tabular}{|c|c|c|c|c|}
\hline & Chick & Starter & Finisher & Pre-slaughter \\
\hline Crude Protein (\%) & 22.49 & 21.53 & 19.25 & 17.97 \\
\hline Crude Cellulose (\%) & 3.00 & 3.00 & 2.72 & 2.93 \\
\hline Crude Fat (\%) & 6.11 & 8.10 & 7.89 & 8.26 \\
\hline Crude Ash (\%) & 4.38 & 4.27 & 3.36 & 3.21 \\
\hline Calcium (Ca) & 1.00 & 0.93 & 0.64 & 0.60 \\
\hline Total Phosphorus (P) & 0.73 & 0.70 & 0.52 & 0.53 \\
\hline Sodium (N) & 0.19 & 0.18 & 0.22 & 0.19 \\
\hline Lysine (\%) & 1.56 & 1.44 & 1.23 & 1.17 \\
\hline Methionine (\%) & 0.78 & 0.58 & 0.50 & 0.53 \\
\hline Vitamin A (IU) & 12500 & 10000 & 5000 & 5000 \\
\hline Vitamin D3 (IU) & 5625 & 4500 & 2250 & 2250 \\
\hline Iron (Ferrum Sulphate Monohydrate \%30, mg) & 20 & 20 & 15 & 10 \\
\hline Copper (Copper Sulphate Pentahydrate, mg) & 16 & 16 & 12 & 8 \\
\hline Zinc (Zinc Oxide \%72, mg) & 110 & 110 & 83 & 55 \\
\hline Manhane (Mangane Oxide \%62, mg) & 120 & 120 & 90 & 60 \\
\hline lodine (Calcium iodide \%10, mg) & 1.25 & 1.25 & 0.94 & 0.63 \\
\hline Selenium (Sodium selenite $\% 4,5, \mathrm{mg}$ ) & 0.30 & 0.30 & 0.25 & 0.15 \\
\hline
\end{tabular}

\section{Equipment Material}

The wing numbers were used to get data individually from the birds (National Band \& Tag, Zip 890, USA). Special plier (National Band \& Tag, Zip 8905 HD) was used. Numbering was done in the first arrival of the chicks. Water storage containers of 20 liters are used in a way that they can be connected to nipples. Drinkers had the opportunity to be adjusted in height (Day-Tav Nipples suluguni Broiler, Turkey). $8 \mathrm{~kg}$ hanging feeders were used as feeders (Day-Tav Hanging feeders $10 \mathrm{~kg}$ Turkey). Digital precision scales were used to weigh both the feed to be given and the animals routinely (Radwag AS220R2, Poland). Glass probe pH probe (WTW Sentix 31, Germany) pH meter was used (WTW 3110, Germany) to measure the hot and cold $\mathrm{pH}$ of meat of the birds slaughtered in the experiment in the industrial plant.

\section{Methods}

The chicks obtained from the company, providing the live and feed material for the study were transferred to the house where the trial was carried out. Following weighing and numbering they were placed in the previously prepared pens. Well water was filled in four of the 20-liter water containers connected to the drinkers in the pens and rainwater was filled in the other four. After the labeling process, 5 kilograms of broiler starter feed was added to the hanging bucket type feeders in the compartments, and the necessary lighting and ventilation systems were arranged.

Body weight and water consumption data were measured at 1, 2, 3, 4, 5 and 6 weeks Mortality was determined daily and replaced from a backup pen with similar conditions to keep stocking density effect stable on trial material. The daily feed and water consumption of the chicks were determined as a group and birds were individually weighed and recorded on a weekly basis.

At the end of the $6^{\text {th }}$ week, live weights were taken and slaughtered by subjecting to the halal standard slaughter procedure in the slaughter unit of the company. After the blood flow of the 
slaughtered animals was completed, the head, internal organs and skin were separated from their carcasses and the carcass weights, and then the heart and gizzard weights were measured and recorded individually. After the weight determination, from the thigh and breast $\mathrm{pH}$ values were measured and recorded with a digital pH meter (WTW 3110, Germany) after slaughter (hot carcass) and 24 hours later (cold carcass).

Harvesting of water was done from a galvanized steel roof with the help of plastic pipes and stored in a tank of 1 ton volume. The water stored was filtered with standard dust filter after application of UV lighting for 30 minutes.

\section{Statistical Analyses}

The study was designed by randomized plot trial plan. Collecting all data and making sure that they are homogeneous. After performing homogeneity tests (skewness and kurtosis analysis followed by the Shapiro-Wilk test), statistical analyses were performed using ANOVA method and Tukey test with SPSS 22 software (SPSS 2013, USA). The findings were shown as means \pm standard error of the means (SEM).

\section{Results and Discussion}

In order to find if harvested rainwater has an effect on performance and some carcass characteristics in broiler rearing; weekly feed, water, individual water, individual feed consumption and weekly feed conversion rates were compared in broilers slaughtered $42^{\text {nd }}$ day (Table 2).

Table 2. The effect of deep well (DW) and harvested rainwater (HR) use on performance in broilers.

\begin{tabular}{|c|c|c|c|c|c|c|c|}
\hline Week & & 1 & 2 & 3 & 4 & 5 & 6 \\
\hline \multicolumn{8}{|l|}{$\begin{array}{l}\text { Performance } \\
\text { Criteria }\end{array}$} \\
\hline \multirow{3}{*}{ Live Weight (g) } & DW & $\begin{array}{l}169.896 \pm \\
2.780\end{array}$ & $\begin{array}{l}430.088 \pm \\
13.500\end{array}$ & $\begin{array}{l}973.513 \pm \\
22.500\end{array}$ & $\begin{array}{l}1498.575 \pm \\
53.600\end{array}$ & $\begin{array}{l}2229.585 \pm \\
63.800\end{array}$ & $\begin{array}{l}2883.585 \pm \\
47.600\end{array}$ \\
\hline & $H R$ & $\begin{array}{l}166.500 \pm \\
2.970\end{array}$ & $\begin{array}{l}443.981 \pm \\
6.560\end{array}$ & $\begin{array}{l}1058.777 \pm \\
34.700\end{array}$ & $\begin{array}{l}1514.450 \pm \\
13.800\end{array}$ & $\begin{array}{l}2221.931 \pm \\
20.300\end{array}$ & $\begin{array}{l}2891.548 \pm \\
35.300\end{array}$ \\
\hline & $P$ & 0.436 & 0.389 & 0.085 & 0.784 & 0.913 & 0.898 \\
\hline \multirow[t]{2}{*}{$\begin{array}{l}\text { Weekly Live } \\
\text { Weight Gain }(\mathrm{g})^{*}\end{array}$} & DW & $\begin{array}{l}119.896 \pm \\
2.780 \\
116.500 \pm \\
2.970\end{array}$ & $\begin{array}{l}260.192 \pm \\
13.100 \\
277.481 \pm \\
4.460\end{array}$ & $\begin{array}{l}543.425 \pm \\
20.600 \\
614.796 \pm \\
30.400 \\
\end{array}$ & $\begin{array}{l}525.063 \pm \\
55.200 \\
455.673 \pm \\
42.300\end{array}$ & $\begin{array}{l}731.010 \pm \\
32.200 \\
707.481 \pm \\
9.280\end{array}$ & $\begin{array}{l}654.000 \pm \\
86.600 \\
669.617 \pm \\
31.900 \\
\end{array}$ \\
\hline & $P$ & 0.436 & 0.258 & 0.100 & 0.357 & 0.509 & 0.871 \\
\hline \multirow[t]{2}{*}{$\begin{array}{l}\text { Weekly Feed } \\
\text { Consumption (g) }\end{array}$} & DW & $\begin{array}{l}2500.000 \pm \\
0.000 \\
2500.000 \pm \\
0.000\end{array}$ & $\begin{array}{l}6487.500 \pm \\
94.400 \\
6600.000 \pm \\
106.000 \\
\end{array}$ & $\begin{array}{l}13987.500 \pm \\
68.800 \\
14125.000 \pm \\
231.000 \\
\end{array}$ & $\begin{array}{l}25075.000 \pm \\
274.000 \\
26125.000 \pm \\
1401.000\end{array}$ & $\begin{array}{l}39200.000 \pm \\
862.000 \\
40000.000 \pm \\
1405.000\end{array}$ & $\begin{array}{l}53450.000 \pm \\
994.000 \\
53500.000 \pm \\
1871.000\end{array}$ \\
\hline & $P$ & 1.000 & 0.458 & 0.590 & 0.490 & 0.645 & 0.982 \\
\hline \multirow{3}{*}{$\begin{array}{l}\text { Weekly Water } \\
\text { Consumption (ml) }\end{array}$} & DW & $\begin{array}{l}6125.000 \pm \\
315.000\end{array}$ & $\begin{array}{l}16375.000 \pm \\
898.000\end{array}$ & $\begin{array}{l}32375.000 \pm \\
1248.000\end{array}$ & $\begin{array}{l}59250.000 \pm \\
1665.000\end{array}$ & $\begin{array}{l}88500.000 \pm \\
1860.000\end{array}$ & $\begin{array}{l}119500.000 \pm \\
2300.000\end{array}$ \\
\hline & $H R$ & $\begin{array}{l}5450.000 \pm \\
210.000\end{array}$ & $\begin{array}{l}17700.000 \pm \\
1175.000\end{array}$ & $\begin{array}{l}33700.000 \pm \\
1175.000 \\
\end{array}$ & $\begin{array}{l}60975.000 \pm \\
1874.000 \\
\end{array}$ & $\begin{array}{l}89725.000 \pm \\
2022.000\end{array}$ & $\begin{array}{l}120725.000 \pm \\
2419.000\end{array}$ \\
\hline & $P$ & 0.125 & 0.405 & 0.469 & 0.517 & 0.671 & 0.726 \\
\hline \multirow{3}{*}{$\begin{array}{l}\text { Individual Feed } \\
\text { Consumption (g) }\end{array}$} & DW & $\begin{array}{l}208.333 \pm \\
0.000\end{array}$ & $\begin{array}{l}336.111 \pm \\
7.860\end{array}$ & $\begin{array}{l}625.000 \pm \\
5.890\end{array}$ & $\begin{array}{l}912.500 \pm \\
26.700\end{array}$ & $\begin{array}{l}1152.778 \pm \\
49.200\end{array}$ & $\begin{array}{l}1222.222 \pm \\
39.900\end{array}$ \\
\hline & $H R$ & $\begin{array}{l}208.333 \pm \\
0.000\end{array}$ & $\begin{array}{l}336.111 \pm \\
8.840 \\
\end{array}$ & $\begin{array}{l}636.111 \pm \\
17.500\end{array}$ & $\begin{array}{l}1055.556 \pm \\
120.000\end{array}$ & $\begin{array}{l}1152.778 \pm \\
35.600\end{array}$ & $\begin{array}{l}1111.111 \pm \\
53.800\end{array}$ \\
\hline & $P$ & 1.000 & 0.458 & 0.746 & 0.459 & 0.743 & 0.387 \\
\hline \multirow{3}{*}{$\begin{array}{l}\text { Individual Water } \\
\text { Consumption (ml) }\end{array}$} & DW & $\begin{array}{l}510.417 \pm \\
26.200\end{array}$ & $\begin{array}{l}854.167 \pm \\
52.400\end{array}$ & $\begin{array}{l}1333.333 \pm \\
48.100\end{array}$ & $\begin{array}{l}2239.583 \pm \\
42.900\end{array}$ & $\begin{array}{l}2437.500 \pm \\
62.500\end{array}$ & $\begin{array}{l}2583.333 \pm \\
48.100\end{array}$ \\
\hline & HR & $\begin{array}{l}454.167 \pm \\
17.500\end{array}$ & $\begin{array}{l}1020.833 \pm \\
92.400 \\
\end{array}$ & $\begin{array}{l}1333.333 \pm \\
34.000 \\
\end{array}$ & $\begin{array}{l}2272.916 \pm \\
80.900\end{array}$ & $\begin{array}{l}2395.833 \pm \\
39.900 \\
\end{array}$ & $\begin{array}{l}2583.333 \pm \\
58.900\end{array}$ \\
\hline & $P$ & 0.125 & 0.168 & 1.000 & 0.728 & 0.595 & 1.000 \\
\hline \multirow{3}{*}{$\begin{array}{l}\text { Feed Conversion } \\
\text { Ratio }\end{array}$} & DW & $1.227 \pm 0.020$ & $1.260 \pm 0.034$ & $1.199 \pm 0.024$ & $1.400 \pm 0.058$ & $1.469 \pm 0.056$ & $1.545 \pm 0.019$ \\
\hline & $\mathrm{HR}$ & $1.252 \pm 0.022$ & $1.239 \pm 0.017$ & $1.114 \pm 0.028$ & $1.436 \pm 0.065$ & $1.500 \pm 0.047$ & $1.541 \pm 0.038$ \\
\hline & P & 0.433 & 0.599 & 0.061 & 0.695 & 0.689 & 0.929 \\
\hline
\end{tabular}


When the data obtained were examined, close numeric body weight and weekly live weight gain were detected between chickens raised with harvested rainwater and chickens raised with deep-well water where water consumption was also found to be parallel.

Live weight (LW) values obtained from the study (Table 2) are in parallel with the LW values they obtained by breeding Hybro broiler genotypes in the studies (Vedet, and Anak 2000; Yetişir et al., 1994) for 7 weeks, respectively 2211.9, 2095.2 and 2048 g. Although Yıldız and Özbey (2000) reported in their studies on the Ross 208, Ross PM3 and Hybro genotypes, it was found to be lower than the LW values our trial. It is thought that the reason for the high LW values of trial data is due to the different line used (Ross 308) and good management. On the other hand, in the studies conducted by Sarica (1997) with the Ross PM3 genotype, the results of the trial were found to be lower than the 2970.66 and $3516.35 \mathrm{~g} \mathrm{LW}$ values reported at $7^{\text {th }}$ week, and this difference is thought to be due to the slaughter age difference.

The weekly live weight gain (WLWG) data obtained from the trial groups are similar to the 118.2, 242.7, 433.02, 525.3 g values reached by Çetin and Yıldız (2017) and was found to be lower than the LWG values reported by Altan et al. (1989). The reason for the low LWG findings obtained in the trial is that Altan et al. (1989) has been using continuous lighting and the feed consumption of animals was higher during the rearing period.

The individual feed consumption amounts (IFC) obtained in the trial performed are similar to the values reported by Karaman and Öcal (2018) and the data reported by Öztürk and Sarıca (1999) in their study. Since the stocking density used by the researchers was higher than our trial, it is thought that the data obtained from LWG was slightly higher.

Individual water consumption (IWC) was found to be higher than the weekly $795.2 \mathrm{ml}$ water consumption data reported by Winchell W (2001), and the reason for this is thought to be due to the application of water restriction in the researcher's study. It was determined that the $2450 \mathrm{ml}$ water consumption findings of Lott (1991) reached in the research findings were higher than the trial findings. The difference was probably arising from the high environmental temperature used by the researcher in his study.

Katelaars (1984) reported the feed conversion rate (FCR) as 1.90. These findings reported by the researcher do not correspond to the findings obtained in the experimental groups. It is estimated that the reason for the inconsistency of the trial findings with the findings of the researcher was due to the high quality of management and stable and good environmental conditions in the study. On the other hand, Viktor et al. (1979) had 1.52 FCR and İşcan (1996) 1.59 which are similar to the findings of the research.

In the trial, weekly body weight, slaughter weight, carcass weight, breast and thigh $\mathrm{pH}$ and edible giblets' (heart, gizzard) weights were determined and compared between the groups in order to examine the carcass characteristics and meat quality (Table 3 and Table 4).

Table 3. The effects of using deep well (DW) and harvested rainwater (HR) in broilers to some carcass parameters.

\begin{tabular}{llc}
\hline Meat Quality Criteria & \\
\hline \multirow{3}{*}{ Carcass Weight (g) } & DW & $2360.000 \pm 60.500$ \\
& HR & $2297.500 \pm 61.200$ \\
\cline { 2 - 3 } & $\mathrm{P}$ & 0.508 \\
\hline \multirow{3}{*}{ Heart Weight (g) } & $\mathrm{DW}$ & $15.667 \pm 0.833$ \\
& $\mathrm{HR}$ & $13.667 \pm 1.420$ \\
\cline { 2 - 3 } & $\mathrm{P}$ & 0.292 \\
\hline \multirow{3}{*}{ Gizzard Weight (g) } & $\mathrm{DW}$ & $43.667 \pm 2.240$ \\
& $\mathrm{HR}$ & $47.000 \pm 1.730$ \\
\cline { 2 - 3 } & $\mathrm{P}$ & 0.305 \\
\hline \multirow{3}{*}{ Heart / Carcass (\%) } & $\mathrm{DW}$ & $0.663 \pm 0.021$ \\
& $\mathrm{HR}$ & $0.593 \pm 0.047$ \\
& $\mathrm{P}$ & 0.240 \\
\hline \multirow{3}{*}{ Gizzard / Carcass (\%) } & $\mathrm{DW}$ & $1.857 \pm 0.140$ \\
\cline { 2 - 3 } & $\mathrm{H}$ & $2.047 \pm 0.079$ \\
\hline
\end{tabular}

As the data obtained from the experimental groups were analyzed, carcass weight (CW) values among the meat quality parameters were determined as $2360 \mathrm{~g}$ in birds given well water and $2297.5 \mathrm{~g}$ in birds given harvested rainwater. The research data obtained from Işcan et al. (1996) has been found to be higher than the 1365 and $1374 \mathrm{~g}$ data reported. The fact that the trial data is higher than the data of other researchers is predicted to have been caused by the lighting restriction practices in the trial studies of the researchers and the animals slaughtered in our study being males.

Heart and gizzard weights reported as 14.6 and $29.0 \mathrm{~g}$, respectively in a trial done by Sarica et al. (2014). From these findings, it was determined that the heart weight was similar to the heart weight obtained from the groups in the trial, and the gizzard was found to be lighter. The high weight of gizzard obtained in the trial should be as a result of slaughtering males. On the other hand, Şahin et al. (2020) reported heart and gizzard weights were 13.3 and $32.2 \mathrm{~g}$, respectively, lower than of the data obtained from the trial. The 
difference is thought to be arising from the fact that data collection and analyzes were carried out on male animals after slaughter and that other researchers used mixed sex live material.

The ratio of heart to carcass reported by Başer (2006) in the research findings is $0.67 \%$ similar to the findings obtained from the groups without trial, but the rate of gizzard to carcass reported $3.08 \%$ was higher than the trial data. On the other hand, it was determined that the heart and gizzard rate data reported by Üzüm (2011) were lower than the data obtained from the trial, $0.53 \%$ and $1.38 \%$, respectively. It is thought that the differences in these two studies were higher or lower than the findings obtained from the experimental groups due to the use of restricted lighting applications.

Table 4. The effects of using deep well (DW) and harvested rainwater (HR) in broilers to breast and thigh meat $\mathrm{pH}$ in hot and cold carcasses.

\begin{tabular}{llccc}
\multicolumn{2}{c}{ Meat $\mathrm{pH}$} & \multicolumn{2}{c}{ Hot Carcass } & \multicolumn{2}{c}{ Cold Carcass } \\
\hline \multirow{3}{*}{$\begin{array}{l}\text { Breast } \\
\text { pH }\end{array}$} & $\mathrm{DW}$ & $6.081 \pm 0.032$ & $5.785 \pm 0.076$ \\
& $\mathrm{HR}$ & $5.893 \pm$ & \pm .091 & $5.865 \pm 0.021$ \\
\cline { 2 - 5 } & $\mathrm{P}$ & 0.125 & \multicolumn{2}{c}{0.335} \\
\hline \multirow{2}{*}{$\begin{array}{l}\text { Thigh } \\
\text { pH }\end{array}$} & $\mathrm{DW}$ & $5.825 \pm$ & 0.040 & $5.945 \pm 0.016$ \\
\cline { 2 - 5 } & $\mathrm{HR}$ & $5.885 \pm$ & \pm .048 & $5.948 \pm 0.016$ \\
\hline
\end{tabular}

Breast and thigh $\mathrm{pH}$ values obtained from the experiment groups were similar to the data reported by Yetişir et al. (2008) as $\mathrm{pH}$ value of 5.80 for breast and 6.40 for thigh, and of Sarica et al (2014) reported thigh $\mathrm{pH}$ value as 5.90 and breast $\mathrm{pH}$ value as 5.89 . This similarity also supports the suitability of slaughtering and post-slaughter processes were in place.

\section{Conclusion}

In the study, it was determined that broilers raised with harvested rainwater and with well water exhibited similar values in terms of live weight and weekly live weight gain, carcass weight like the $\mathrm{pH}$ values in thigh and breast meat.

In the light of these findings, it can be told that the harvested rainwater can be used as an alternative to well water, which is widely used in broiler breeding, without adverse effects on performance and meat quality in general.

Especially in regions with abundant rainfall, where it is difficult to obtain well water and lack of water due to drought, harvested rainwater can be used as drinking water in broiler rearing also thought to be economically beneficial by reducing electricity and other maintenance costs.

When all the findings are examined in general, it can be said that harvested rainwater can be used as drinking water in broiler breeding in terms of performance, inspected carcass and focused meat quality parameters. It has been found that there are very few and limited studies on this subject. It is considered and recommended to conduct more comprehensive new studies, including the health status, internal organ microbiology and economy level of the harvested rainwater with more detailed and higher quantity live material, taking into consideration of the findings of this study.

\&: Yüksek lisans tezinden üretilmiştir.

Acknowledgement: We would like to thank to BAIBÜ Faculty of Agriculture, Department of Poultry Science for the equipment used. The manuscript was compiled from the masters thesis "The effects of harvested rainwater on the performance of broilers" ("Hasat edilmiş yağmur suyunun etlik piliçlerde performansa etkileri") with YökTez ID 640737.

Conflict of Interest: The researchers declare that there is no conflict of interest.

\section{References}

Alparslan, N., Tanık, A. ve Dölgen, D. 2008. Türkiye'de Su Yönetimi-Sorunlar ve Öneriler, TÜSiAD Yayın No: T/2008-09/469.

Altan, Ö., Altan, A., Koçak, Ç. ve Oğuz, í. 1989. Etlik Piliçlerde Farklı Aydınlatma Yöntemlerinin Verim Özelliklerine Etkisi, Ege Üniversitesi Ziraat Fakültesi Dergisi, 26(3): 93-99.

Anonymous 2020a. Türkiye Geneli Yıllık Alansal Yağışları, https://www.mgm.gov.tr/veridegerlendirm e/yillik-toplam-yagis-verileri.aspx, Haziran 2020.

Anonymous 2020b. Türkiye Kişi Başına Et Tüketimi, https://www.tarimorman.gov.tr/HAYGEM/B elgeler/Hayvanc\%C4\%B1I\%C4\%B1k/Kanatl\% C4\%B1\%20Yeti\%C5\%9Ftiricili\%C4\%9Fi/Etlik \%20Pili\%C3\%A7\%20Yetistiriciligi.pdf, 23 Haziran 2020.

Başer, E. 2006. Farklı Aydınlatma Programları ile Mısır ve Tritikale Esaslı Rasyonların Etlik Piliçlerin Verim Performansı Karkas Özellikleri ve Yağlanması Üzerine Etkileri, Doktora Tezi, Selçuk Üniversitesi, Fen Bilimleri Enstitüsü, Konya. 
Bayramoğlu, E., Ertek, A. ve Demirel, Ö. 2013. Su Tasarrufu Amacıyla Peyzaj Mimarlığı Uygulamalarında Kısıntılı Sulama Yaklaşımı, İnönü Üniversitesi Sanat ve Tasarım Dergisi, 3(7), 45-53.

Çetin, T. ve Yıldız, G. 2017. Uçucu Yağların Etlik Piliçlerde Besi Performansı, Karkas Randımanı, Newcastle Hastalığı ve Enfeksiyöz Bronşitis Antikor Seviyeleri ile Bazı Serum Parametreleri Üzerine Etkisi, Veteriner Hekimler Derneği Dergisi, 88(2): 51-67.

Eleroğlu, H. ve Sarıca, M. 2004. Kanatlı Üretiminde İçme Suyu Kalitesi 4. Ulusal Zootekni Bilim Kongresi, 318-324, Isparta.

Incebel, C. 2012. Alternatif Su Kaynaklarının Endüstriyel Kullanıma Kazandırılması İçin Çatı Yağmur Suyu Hasadı (Ostim örneği), Yüksek Lisans Tezi, Gazi Üniversitesi Fen Bilimleri Enstitüsü, Ankara.

İscan, KM., İnal, Ş., Dere, S., Azman, MA. ve Ünsaldı, T. 1996. Live Performance and Carcass Yields Of Broilers In Different Intermittent Lighting Schedules, Turk. J. Vet. Animal Science, 20: 337-340.

Kantaroğlu, Ö. 2009. Yağmur Suyu Hasadı Plan ve Hesaplama Prensipleri, IX. Ulusal Tesisat Mühendisliği Kongresi.

Karahan, A. 2011. Gri Suyun Değerlendirilmesi, IX. Ulusal Teisat Mühendisliği Kongresi, 11551164.

Karaman, M. and Öcal, M. 2018. The effect of light regimen and feeding time on growth performance and mortality rate in broiler. Turkish Journal of Agriculture-Food Science and Technology, 6(1): 91-96.

Leeson, S. and Summers, JD. 2008. Commercial Poultry Nutrition-3rd Edition, University Books, Ontario, Canada.

Lott, BD. 1991. The Effect of Feed Intake on Body Temprature and Water Consumption of Male Broilers During Heat Exposure, Poultry Science, 70: 756-759

Örs, İ., Safi, S., Ünlükara, A. ve Yürekli, K. 2011. Su Hasadı Teknikleri, Yapıları ve Etkileri, Tarım Bilimleri Araştırma Dergisi 4(2): 65-71.

Öztürk, E. ve Sarıca, M. 1999. Bitirme Döneminde Yem Kısıtlamasının Etlik Piliçlerin Performansına ve Karkas Kalitesine Etkileri, Turkish Journal of Veterinary and Animal Science, 23(Ek Sayı 2): 343-350.
Sarıca, M. 1997. The Effects of Slaughter Age On Carcass Traits of Broilers, Türk J. Vet. and Anim. Sci. 21(5): 413-420.

Sarıca, M., Ceyhan, V., Yamak, S., Uçar, A. ve Boz, M. 2014. Yavaş Gelişen Sentetik Etlik Piliç Genotipleri ile Ticari Etlik Piliçlerin Büyüme, Karkas Özellikleri ve Bazı Ekonomik Parametreler Bakımından Karşılaştırılması, Tarım Bilimleri Dergisi, 22: 20-31.

Silkin, H. 2014. İklim Değişikliğine Uyum Özelinde Bazı Uygulamaların Türkiye Açısından Değerlendirilmesi, T.C. Orman ve Su İşleri Bakanlığı Su Yönetimi Genel Müdürlüğü, Orman ve Su işleri Uzmanlık Tezi, Ankara.

Şahin, N. ve Manioğlu, G. 2011. Binalarda Yağmur Suyunun Kullanılması, Tesisat Mühendisliği, 125: 21-32.

Şahin, T., Sural, T., Ölmez, M. ve Karadağoğlu, Ö. 2020. Bitkisel Ekstrakt Karışımlarının Broylerlerde Performans, Karkas Randımanı ve Bazı İç Organ Ağırlıkları Üzerine Etkisi, Veteriner Hekimler Dernegi Dergisi, 91(2): 137-146.

Tanık, A. 2017. iтü İnşaat Fakültesi, Çevre Mühendisliği Bölümü Su Kaynakları ve Kentler Konferansı, Kahramanmaraş, 2017.

Üzüm, M. 2011. Sıcak Stresi Altındaki Boylerlerde Yerleşim Sıklığı ve Yem Kısıtlamasının Performans, Karkas ve Et Kalite Özellikleri ile Bazı Stres Parametreleri Üzerine Etkileri, Yüksek Lisans Tezi, Sağlık Bilimleri Enstitüsü, Aydın.

Winchell, W. 2001 Water Requirements For Poultry: Water Quantity, https://docplayer.biz.tr/amp/10577637-

Turk-tarim-gida-bilim-ve-teknolojidergisi.html, 19 Nisan 2020.

Yetişir, R. ve Dıvarcı, S. 1994. Genotip, Cinsiyet Ve Kesim Yaşının, Boylerlerde Kesim Sonuçları ve Karkas Parça Oranlarına Etkileri ve Canlı Ağırlık Parça Ağırlığı illişkileri, Selçuk Üniversitesi Ziraat Fakültesi Dergisi 5(7): 141-163.

Yetişir, R., Karakaya, M., İlhan, F., Yılmaz, M. ve Özalp, B. 2008. Tüketici Tercihini Etkileyen Bazı Piliç Eti Kalite Özellikleri Üzerine Farklı Aydınlatma Programları ve Cinsiyetin Etkileri, Hayvansal Üretim, 49(1): 20-28.

Yıldız N ve Özbey O (2000) "Farklı Genotip Broyler Hibritlerin Aynı Çevre Şartlarında Verim Özellikleri", Yüzüncü Yıl Üniversitesi Veteriner Fakültesi Dergisi, 11(2): 44-49. 